\title{
Management of Fractures of Distal third Tibia by Interlock Nailing
}

${ }^{1}$ Satish R Gawali, ${ }^{2}$ Shashikant B Kukale, ${ }^{3}$ Pramod V Nirvane, ${ }^{4}$ Raman 0 Toshniwal

\section{ABSTRACT}

Introduction: Most of the distal third tibia is subcutaneous and has precarious blood supply. Fractures of the distal third tibia have comminution at the fracture site, as it is metaphyseal cancellous bone with a thin shell of cortex, and have associated significant soft tissue injury. Generally, skin condition is not satisfactory due to ecchymosis, blebs, swellings, wounds, etc. All these factors contribute to delayed union, nonunion, and malunion.

The present study is about the ability to maintain a mechanically stable reduction in the distal third tibia with intramedullary nail, when lower $4 \mathrm{~cm}$ of tibia not fractured. If associated with fibula fracture (in lower $10 \mathrm{~cm}$ ), it is always fixed as a rule to give stability to syndesmosis and stability to same-level tibia fracture.

Materials and methods: From January 2013 to March 2015, 60 patients of distal tibia fracture admitted to Government Medical College and Hospital, Latur, were operated and followed up prospectively.

Results: Mean age of patients was 35 years (25-50). Fracture union was seen radiologically within 3 to 4 months, depending on fracture geometry.

Conclusion: We conclude that results of fractures of distal third tibia not extending into lower $4 \mathrm{~cm}$ of tibia treated with interlock nailing were found satisfactory. Meticulous planning and placement of nail at the center of a wide metaphysis in the anteroposterior and lateral is mandatory to avoid varus, valgus, and posterior tilt. Polar screw or temporary K-wire during surgery is very helpful. Same-level fibula fracture fixation with a plate or square nail is very effective for stability of reduction.

Keywords: Fibula fixation, Fracture distal third tibia, Interlock tibia nailing.

How to cite this article: Gawali SR, Kukale SB, Nirvane PV, Toshniwal RO. Management of Fractures of Distal third Tibia by Interlock Nailing. J Foot Ankle Surg (Asia-Pacific) 2016;3(1):15-22.

Source of support: Nil

Conflict of interest: None

\footnotetext{
${ }^{1}$ Associate Professor, ${ }^{2}$ Assistant Professor, ${ }^{3}$ Senior Resident ${ }^{4}$ Resident

${ }^{1-4}$ Department of Orthopedics, Government Medical College and Hospital, Latur, Maharashtra, India

Corresponding Author: Satish R Gawali, Associate Professor Department of Orthopedics, Government Medical College and Hospital, Latur, Maharashtra, India, Phone: +919422611201 e-mail: satishgawali61@gmail.com
}

\section{INTRODUCTION}

Fractures of the distal third tibia are different, in that the bone is subcutaneous with no muscle covering on the anteromedial aspect and consequently less blood supply to the tibia. This precarious vascularity, as compared to other long bones, may lead to delayed union or nonunion. Treatment remains a major substantial therapeutic challenge in orthopedic trauma; considering its anatomy, it is difficult to achieve reduction and maintain it owing to wide metaphysis, bad skin condition, and fracture comminution. ${ }^{2}$ In addition, it is even more difficult if fibula fractures are at the same level, which contribute to additional mechanical instability and associated syndesmotic injury if fibula fractures are in the lower $10 \mathrm{~cm}$.

Various modalities are available, such as:

- Interlock Nailing

- External fixation spanning ankle joint

- Minimally invasive plate osteosynthesis (MIPO) with locking plates

\section{Intramedullary Nailing}

Intramedullary nailing is indicated for the majority of closed lower third tibia and middle and lower third junction fractures of the tibia ${ }^{3}$ as well as for open fractures with adequate soft tissue cover when fracture is not extending into the lower $4 \mathrm{~cm}$ of tibia from the ankle joint. $^{4}$

\section{Minimally Invasive Plate Osteosynthesis with Locking Plates}

Displaced, unstable fractures of distal third of tibia, mainly fractures within $3 \mathrm{~cm}$ from ankle joint - with or without articular involvement ${ }^{5}$ - provide best indications for plating, particularly when skin envelop is good and patient can afford; Patients treated with MIPPO are not included in the present study.

\section{Advantages of Closed Nailing over Plating}

- In closed nailing, fracture hematoma is preserved, which is vital and essential for fracture healing; hence, it yields high union rate.

- Being intramedullary, it acts as a load-sharing implant. So, early weight bearing can be started, as against plating, which is a load-bearing implant 
and weight bearing should be allowed after fracture union.

- Advantage of controlled impaction over nail during surgery.

- Two screws proximal and two to three screws in distal fragments give better rotational stability.

- Shorter operative time, less soft tissue dissection, less blood loss, and hence reduced rate of infection.

- Reaming itself gives advantage of internal bone graft at fracture site at the time of reaming. In communited fracture, reamer should be just pushed and negotiated across communited fragments without rotatory movement.

Reamed intramedullary nails are preferred for closed fractures, as reaming allows the use of implants of larger diameter and offers a high union rate. ${ }^{6}$ The solid so-called unreamed nails are presently preferred to the external fixator ${ }^{7}$ as the implant of choice for most open tibial fractures at the lower third tibia - when fractures do not extend within $4 \mathrm{~cm}$ of distal tibial end, i.e., from the ankle joint.

The soft tissue envelop is the most important component in the evaluation and subsequent care of tibial fractures. Fracture blisters are a sign of massive soft tissue injury, and are a warning to delay any intervention. So, the extent and location of swelling and bruises are assessed first. Hemorrhagic blisters call for more attention than do routine blisters as they indicate underlying skin necrosis.

Timing of surgery is determined by the conditions of soft tissue. Simple fractures can be definitively stabilized within 6 to 8 hours. For other cases with bad skin condition, surgery can be delayed, till edema subsides and skin begins to wrinkle. Limb elevation, edema-relieving drugs, local $\mathrm{MgSO}_{4}$ dressing, and ice application are of use to relieve edema.

\section{MATERIALS AND METHODS}

We used Müllers AO classification for fractures of distal tibia. According to it, distal tibia fractures are classified into three categories.

\section{Muller's AO Classification of Closed Fractures}

- Type 43A: Extraarticular fracture, metaphyseal simple, wedge, or complex.

- Type 43B: Partial articular fracture, split and/or depression.

- Type 43C: Complete articular fracture; simple, multifragmentary.

Between January 2013 and March 2015, patients with fracture distal third tibia with intact lower $4 \mathrm{~cm}$ of tibia (fracture should be extraarticular AO type 43A) admitted in our hospital were included.

\section{Exclusion Criteria}

Fracture with articular involvement (type 43B, type 43C), fracture within $4 \mathrm{~cm}$ of ankle joint, pathological fracture, and patients with unstable cardiorespiratory status who were not fit for anesthesia were excluded.

Evaluation of fracture morphology, level of fracture, and its extent was carried out, and accordingly, surgery planned with anesthetic fitness and evaluation of local skin condition.

Anteroposterior and lateral radiographs of the affected leg with knee and ankle joint were taken and evaluated for fracture morphology, level, and extent of comminution. ${ }^{8}$ The fibular fracture was noted, and surgery planned accordingly to fix the fibula. The leg was immobilized in a plaster slab till definitive surgery. Patients with poor skin condition ${ }^{9}$ were managed with limb elevation, local magnesium sulfate dressing, and anti-edema drugs (serratiopeptidase, trypsin, chymotrypsin, Bromelain, etc.). Patients with compound fractures were taken for immediate debridement under regional anesthesia. It was followed by regular dressing, along with intravenous antibiotics.

Routine laboatory investigations included $\mathrm{HB}, \mathrm{CBC}$, BSL, LFT.KFT, HIV, HBSAG, ECG, and CXR.

Surgery was delayed in poor skin conditions till appearance of the wrinkle, but performed as soon as possible with anesthetic fitness.

\section{Operative Technique: Intramedullary Nailing}

Surgery was performed under tourniquet and spinal anesthesia under image intensifier tele vision (IITV) control on radiolucent fracture table. Routine antiseptic wash and scrubbing with povidone iodine scrub was done. It was followed by painting with povidone iodine and draping of the operative area. The surgery was carried out under tourniquet to achieve bloodless operative field and to decrease blood loss.

- Fractures are reduced by closed methods of gentle traction and external manipulation and guide wire passed and fixed in a central position ${ }^{10}$ in both AP and lateral view and IITV control (Figs 1 and 2) reamed intramedullary nailing done.

- In treating distal third fractures, it is advisable to use temporary polar screw or thick K-wire, so that guide wire, reamer, and subsequent intramedullary nail remain in the center (as there is widening of medullary canal at the diaphysio-metaphyseal junction) so that varus/valgus or anterior posterior angulation can be avoided. ${ }^{11}$ Special attention is given for fixation of fibula with third tubular plate or square nail with posterolateral approach (Figs 3 and 4). 

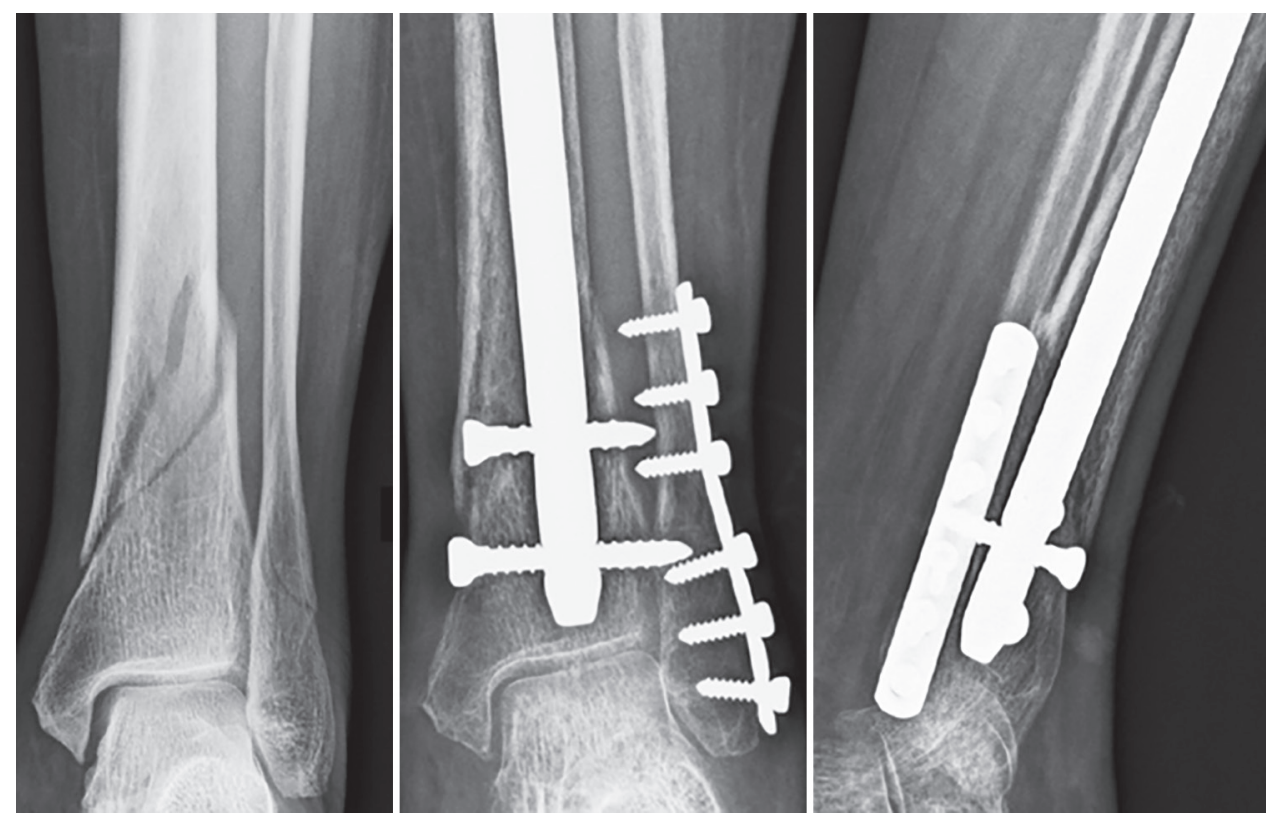

Fig. 1: Intraoperative images of insertion of guide wire and subsequent insertion of nail after reaming
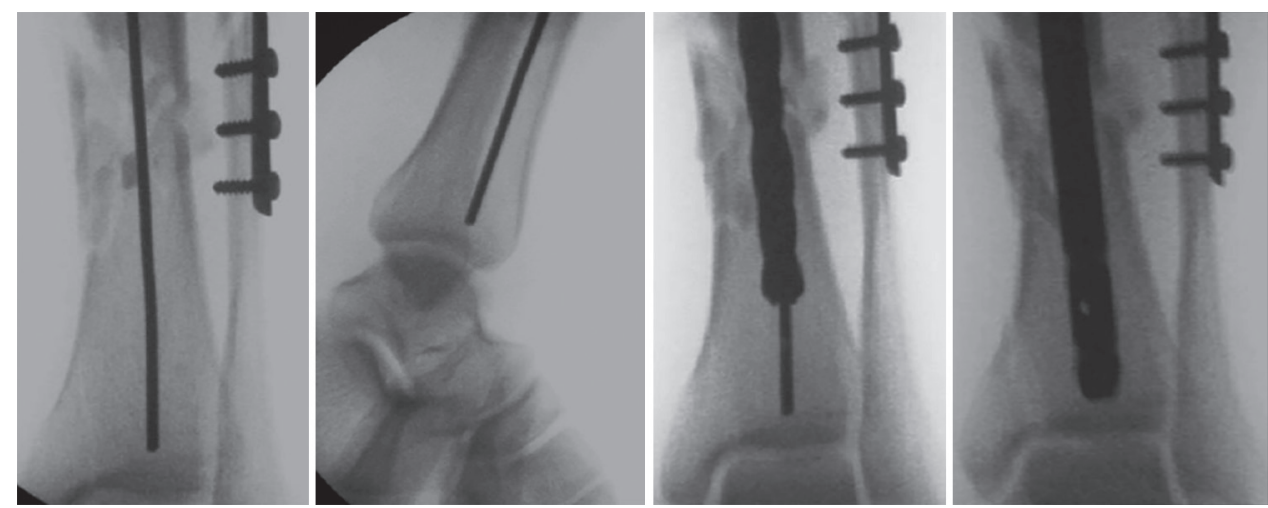

Fig. 2: Mediolateral and anteroposterior locking screw fixation
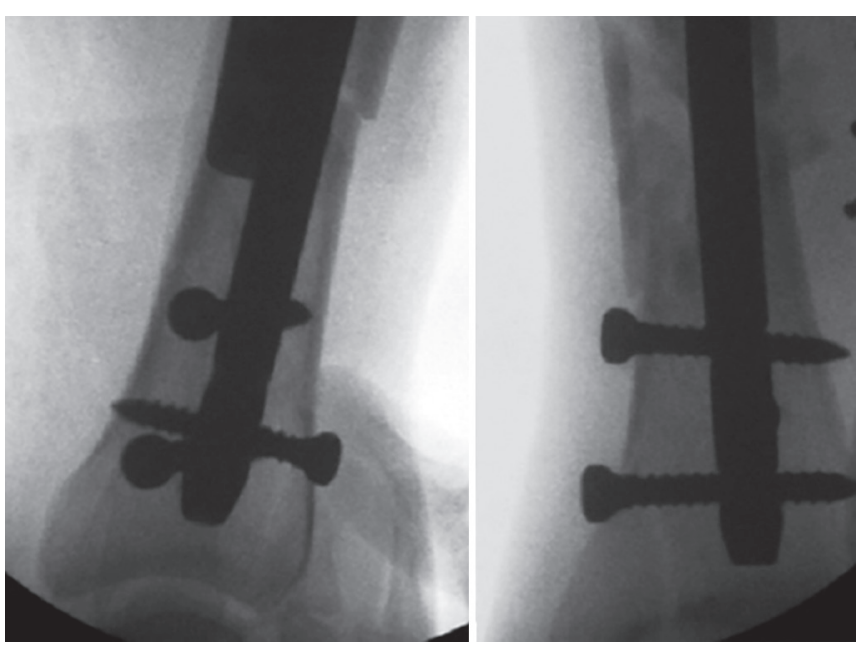

Fig. 3: Fracture of distal tibia fibula /3rd united with intramedullary nail and fibula plating

- Guide wire placement in distal fragment should be central in AP and lateral, so that subsequent reaming and nail insertion comes in ideal central position.
- Polar screw or temporary thick K-wire was very useful to direct the nail in a central position.

- Nail should be driven up to the subchondral level at the ankle plafond ${ }^{12}$ (Fig. 5). An expert tibia nail has three interlocking options at distal sites: Two medial to lateral and one anteroposterior.

- We preferably lock all three sites if feasible or at least two bolts one medial to lateral and one anteroposterior (Fig. 6). Care has to be taken not to leave empty locking holes at the fracture site as there is high incidence of nail breakage at empty locking holes when assessment of reduction was done repeatedly by C-arm image control and angulation, rotational alignment, length of tibia, and fibula corrected during procedure.

- Postoperatively, limb elevation and below-knee POP slab was given, as well as third-generation cephalosporin and amino glycosides were given intravenously for 3 days and oral antibiotics continued till 7th postoperative day. Check X-rays were taken. 


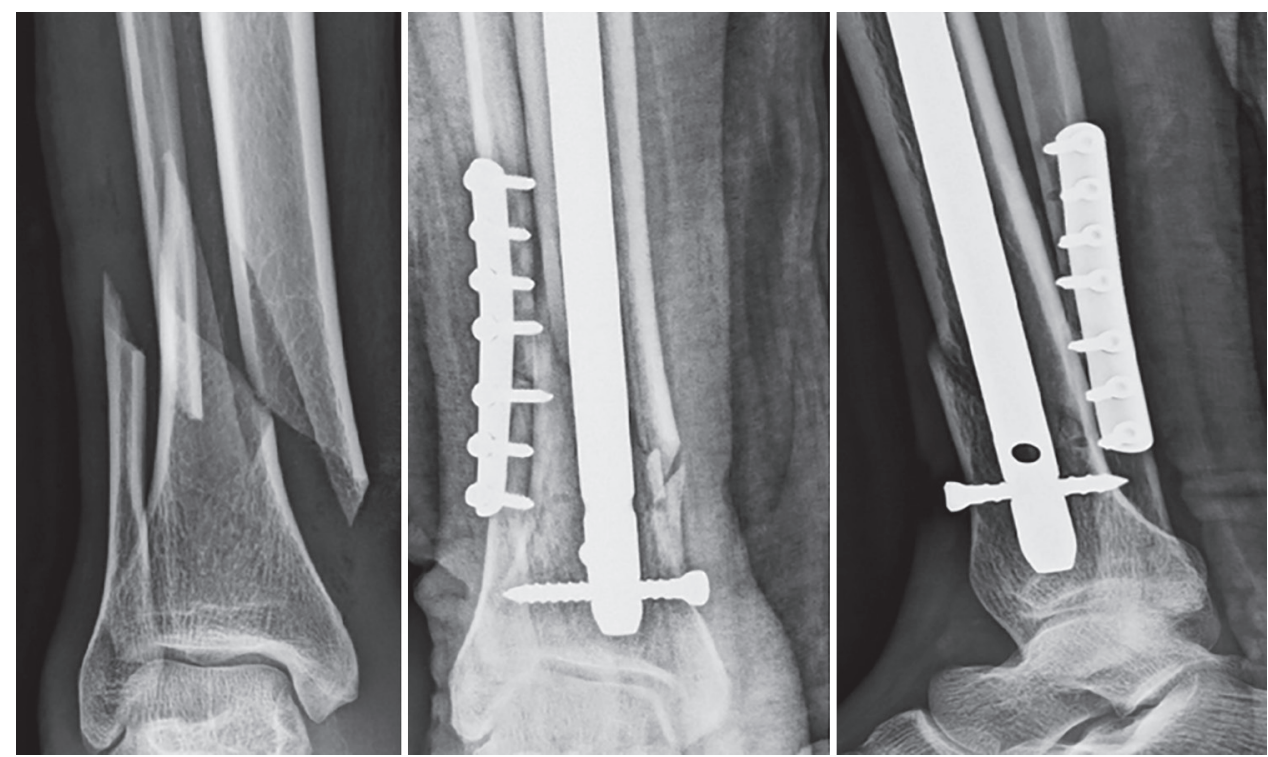

Fig. 4: Fixation with intramedullary nail and square nailing of fibula

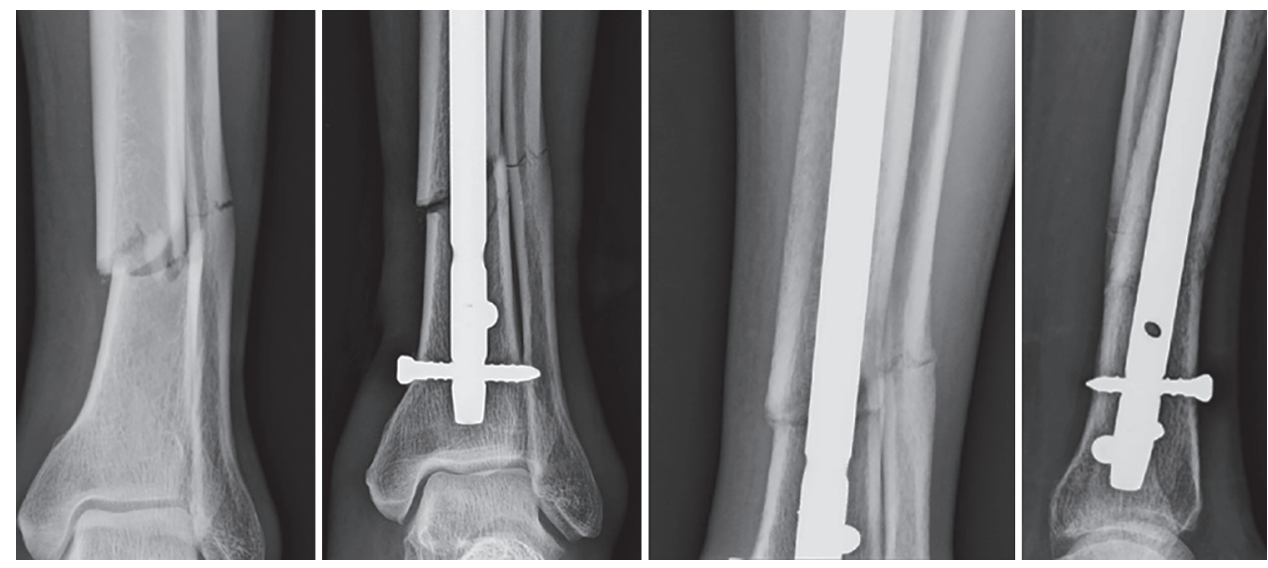

Fig. 5: Intramedullary nail and one AP and one mediolateral screw
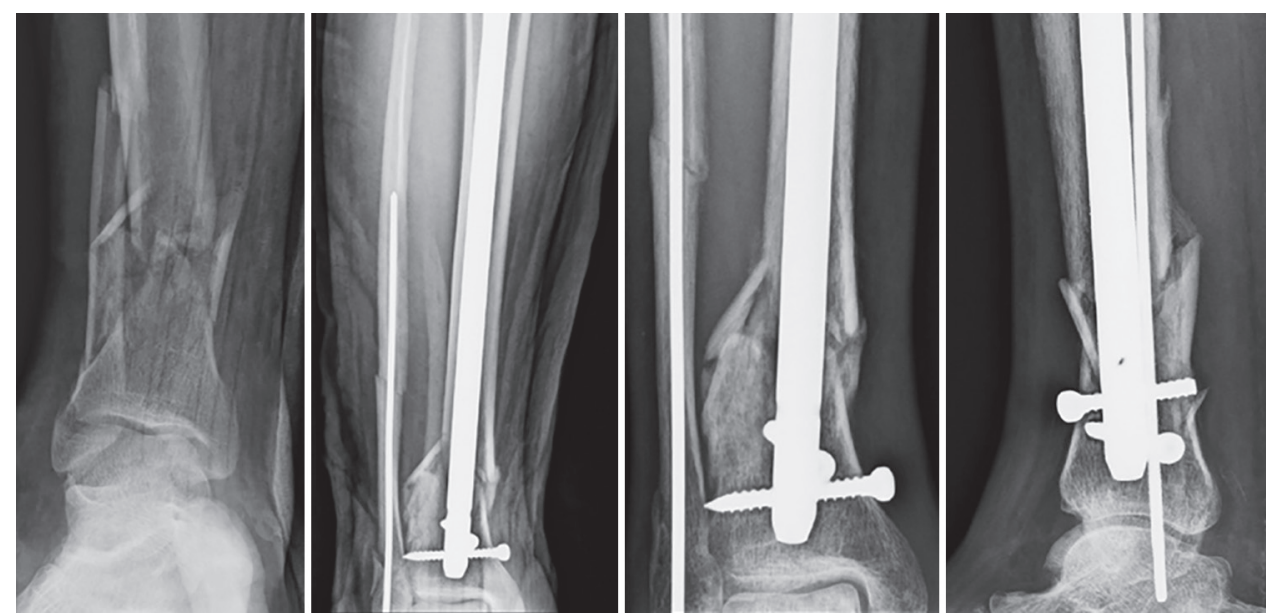

Fig. 6: Preoperative and postoperative AP and lateral

- Range of motion of ankle and knee started postoperatively on 3rd day after first check dress after temporary removal of slab, if reduction is stable. Wound assessment was made with second check dressing on the 7th postoperative day.
- Partial weight bearing was not allowed in first 4 to 6 weeks, depending on fracture configuration and stability of reduction. Patients were reassessed clinically and radiologically for progress of fracture union. Accordingly, weight bearing up to 50 to $75 \%$ was advised. 
- Follow-up X-rays of cases were taken on 4 th, 8 th, and 12th weeks, and every 6 weeks thereafter until clinical and radiological union was seen. Partial (toe touch) weight bearing started on the 4th week.

- Results including early and late complications (malunion) and final outcome assessed.

\section{RESULTS}

In our study, 60 patients of age group 25 to 50 years were included.

There were 48 males and 12 females. Mode of injury was road traffic accident in majority of cases.

There were 50 closed and 7 compound grades I, 2 compound grade II, and 1 grade III (Gustilo Anderson Classification).

Closed intramedullary nailing was done in all 60 cases; Of which, 40 patients had no other fixation besides tibia nail. Mean operation time was 89 minutes (80-96 minutes).

Tables 1 and 2 show that the mean radiation time was 2.6 minutes $(2.5-2.7)$.
One patient with grade 3III B fracture was initially treated with debridement and external fixator, and fixed with intramedullary nail after wound healing (Fig. 5).

In 20 patients, CRIF and nailing with additional fibula fixation (with square nail fibula or with $1 / 3$ tubular plating) was done (Figs 4 and 6).

Complications were found in five patients. Superficial infection (4 cases) were treated with daily dressing and broad-spectrum antibiotics, and deep infection (1 case) that presented as compound grade III injury needed implant removal and debridement after fracture union (Fig. 7). Union of fracture was evident in both cases.

Radiological and clinical union was evident in all patients with average duration of 18 weeks (16-20; Table 2).

In Yang et al, ${ }^{13}$ patients with AO type $43 \mathrm{~A}$ fractures All fibular fractures were first stabilized with plate fixation. The tibial fractures were treated with a locked IM tibial nail

In the Mugundhan Sengodan ${ }^{14}$ study, they evaluated clinical use of blocking screws as a supplement to stability

Table 1: Demographic data

\begin{tabular}{llllc}
\hline Sl. no. & Parameter & SW Yang et al ${ }^{13}$ & Mugundhan Sengodan $^{14}$ & Our study \\
\hline 1 & Number of patients & 13 & 20 & 60 \\
2 & M:F & $8: 5$ & $16: 4$ & $40: 20$ \\
3 & Age & $48.2 \pm 19$ & 35 & 35 \\
4 & Union time (weeks) & $22.6 \pm 4.3$ & 11.5 & 18.0 \\
5 & Varus/valgus angulation & $3.7 \pm 3.3$ & \pm 1.7 & \pm 1.5 \\
6 & Postoperative recurvatum & $1.7 \pm 2.6$ & -0.1 to $0.5( \pm 0.2)$ & -0.1 to $0.3( \pm 0.2)$ \\
7 & No. of Malunions & 03 & - & 03 \\
\hline
\end{tabular}

Table 2: Mean perioperative time duration

\begin{tabular}{lll}
\hline Parameters & JJ Guo et all5 & Our study \\
\hline Mean $(95 \% \mathrm{Cl})$ operating time (in minutes) & $81.23(77.72-84.73)$ & $89.00(80.00-96.00)$ \\
Mean $(95 \% \mathrm{Cl})$ radiation time (in minutes) & $2.2(2.1-2.3)$ & $2.6(2.5-2.7)$ \\
Mean $(95 \% \mathrm{Cl})$ time to union (in weeks) & $17.7(16.7-18.6)$ & $18(18-20)$ \\
Patients with wound problems (\%) & $3(6.8)$ & $4(6.6)$ \\
\hline
\end{tabular}
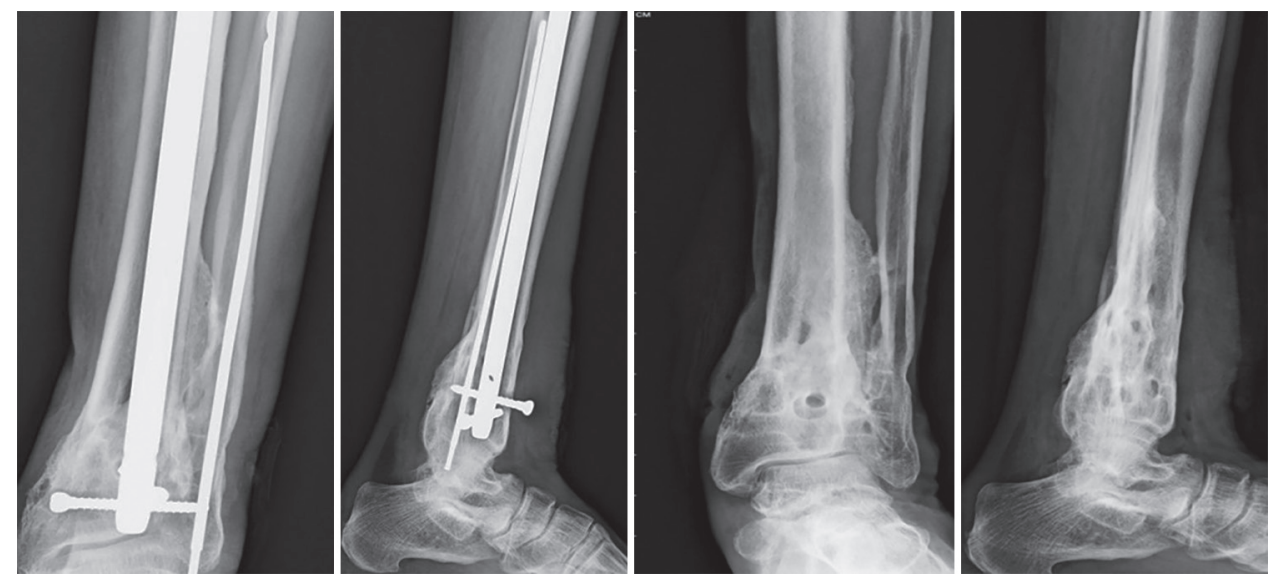

Fig. 7: Implant removal (united fracture) 
Table 3: Karlstrom-olerud for evaluation of results

\begin{tabular}{lllll}
\hline Sl. no. & Measure & 3 points & 2 points & 1 point \\
\hline 1 & Pain & No & Little & Severe \\
2 & Difficulty in walking & No & Moderate & Severe/limp \\
3 & Difficulty in climbing stairs & No & Supported & Unable \\
4 & Difficulty in previous sports & No & Some sports & Unable \\
5 & Limitation at work & No & Moderate & Unable \\
6 & Status of skin & Normal & Various colours & Ulcer/fistula \\
7 & Deformity & No & Little, $<7^{\circ}$ & Remarkable,,$>7^{\circ}$ \\
8 & Muscle atrophy & $<1 \mathrm{~cm}$ & $1-2 \mathrm{~cm}$ & $>2 \mathrm{~cm}$ \\
9 & Leg length discrepancy & $<1 \mathrm{~cm}$ & $1-2 \mathrm{~cm}$ & $>2 \mathrm{~cm}$ \\
10 & Loss of motion at knee joint & $<10^{\circ}$ & $10-20^{\circ}$ & $>20^{\circ}$ \\
11 & Loss of motion at subtalar joint & $<10^{\circ}$ & $10-20^{\circ}$ & $>20^{\circ}$ \\
\hline
\end{tabular}

in distal tibial metaphyseal fractures treated with statically locked intramedullary nail (Table 2).

In our series, mean union time is 18 weeks (16-20), with varus/valgus angulation of $\pm 1.5^{\circ}$ with recurvatum of $( \pm 0.2)$.

\section{DISCUSSION}

We use modified functional evaluation system by Karlstrom-Olerud for evaluation of results (Table 3).

Treating tibial distal third fractures associated with fibular fracture at the same level becomes even more difficult. This fracture pattern reflects a high-energy trauma causing significant soft tissue injury and gross comminution. Another clinical concern was:

- In the distal $1 / 3$ rd tibia, the medullary canal is wide and in comparison, the diameter of the nail is less, So it reduces mechanical stability in lateral to medial plane and sometimes it calls for use of polar screw.

- When the fibula is fractured within $10 \mathrm{~cm}$ of the ankle joint, the ankle syndesmotic stability is jeopardized and needs stable fixation.

The ability to maintain a mechanically stable reduction with intramedullary nail becomes more difficult when fracture extends distally and when there is metaphyseal comminution.

Modern tibial nail designs have interlocking holes that enable distal placement of screw in close proximity to the tip of the nail, but these screws have less purchase in metaphyseal bone; there is increased stress on the screw to maintain fracture alignment as compared to locking screws in diaphysis and diaphysio-metaphyseal junction. ${ }^{13}$

With regard to complications in particular skin problems, infections are very less as compared to locking plate fixation.

Biomechanical studies in cadavers showed that fibular fracture fixation associated with tibial distal fracture treated with locked intramedullary nail reduces angular deviations and angular alignment and in increasing fracture stability and helps in achieving better union rate (Figs 6 and 7). It also helps to avoid the windshield wiper effect between locking screw and the nail hole, which favors varus/valgus movements of the screw. Mosheiff et $\mathrm{al}^{7}$ and Tyllianakis et al ${ }^{12}$ treating with fibular fixation, reported a low trend of tibial deformities. Dogra et $\mathrm{al}^{16}$ reported that in 3 patients of the 15 of their series presented angle in varus or valgus $>5^{\circ}$, without fibular fixation. Schmidt et $\mathrm{al}^{10}$ reported that fibular fixation must be performed before fixating tibia with intramedullary nail when there is a major fibular deviation, because this helps on restoring the alignment of the limb or when there is gross tibial comminution. Goldsztajn et a ${ }^{20}$ treated 26 patients with intramedullary nail and found $88.5 \%$ of anatomical reduction of the tibia at early postoperative period, without requiring fibular fracture fixation.

- In the Dogra et al study, ${ }^{16}$ three (20\%) patients had varus/valgus angulation $>5^{\circ}$ as they had not fixed the lower third fibula fracture. This malunion is $20 \%$, which is significantly more than our series $(5 \%)$

Table 4: Comparison between fibula fixation and malunion

\begin{tabular}{lllllll}
\hline & & & \multicolumn{2}{c}{ No. of patients } & & \\
\cline { 3 - 4 } SI. no. & Study & Type & Total & Fibula fixation nn & Union (weeks) & Complications malunion \\
\hline A & Pedro Labronici et al ${ }^{17}$ & Comparative & 21 & 16 & 14.6 & Varus $(4.3 \%)$ \\
& & & & & Valgus $(2.2 \%)$ \\
B & Dogra et al ${ }^{16}$ & Retrospective & 15 & 00 & $12-20$ & $03(20 \%)$ \\
C & Our study & Prospective & 60 & 20 & 18 & $03(5 \%)$ \\
\hline
\end{tabular}


Management of Fractures of Distal third Tibia by Interlock Nailing

\begin{tabular}{|c|c|c|c|c|c|c|}
\hline $\begin{array}{l}\text { SI. } \\
\text { no. }\end{array}$ & Study & Type & $\begin{array}{l}\text { No. of } \\
\text { patients }\end{array}$ & Union (weeks) & Outcome & Complications \\
\hline 1 & Mosheiff et al ${ }^{7}$ & Prospective & 52 & 15.3 weeks & $50 / 52$ & $\begin{array}{l}02 \text { Infections (Open fractures) } \\
02 \text { Nonunion with nail breakage }\end{array}$ \\
\hline 2 & Tyllianakis et al ${ }^{12}$ & Retrospective & 73 & $\begin{array}{l}4.2 \text { months } \\
18 \text { weeks }\end{array}$ & $\begin{array}{l}70 / 73 \\
95.89 \%\end{array}$ & - \\
\hline 3 & Nork et al ${ }^{18}$ & Prospective & 36 & $\begin{array}{l}23.5 \text { weeks } \\
(13-17 \text { weeks })\end{array}$ & $92.00 \%$ & $\begin{array}{l}01 \text { Deep infection } \\
01 \text { Latrogenic fracture }\end{array}$ \\
\hline 4 & Fan et al ${ }^{19}$ & Prospective & 20 & $\begin{array}{l}17.2 \text { weeks } \\
\text { (12-28 weeks) }\end{array}$ & $100 \%$ & - \\
\hline 5 & Dogra et $\mathrm{al}^{16}$ & $\begin{array}{l}\text { Retrospective (Fibula } \\
\text { fixation not done) }\end{array}$ & 15 & $12-20$ weeks & $\begin{array}{l}100 \% \text { ( } 03 \text { needed } \\
\text { secondary procedure) }\end{array}$ & $\begin{array}{l}02 \text { Nail dynamization } \\
01 \text { Exchange nail with bone graft }\end{array}$ \\
\hline 6 & Our study & Prospective & 60 & $18(16-20)$ & $100 \%$ & $\begin{array}{l}03 \text { Malunion } \\
04 \text { Superficial infection } \\
01 \text { Deep infection }\end{array}$ \\
\hline
\end{tabular}

- In our study, we did stabilization of fibula fracture in 20 out of total 60 patients. Three patients had (5\%) malunion at final outcome (Table 4).

Complications were found in five patients. Superficial infection (04) treated with daily dressing and broadspectrum antibiotics. Deep infection (01) presented as Compound grade III injury, which needed implant removal and debridement after fracture union (Fig. 7). Union of fracture was evident in both the cases.

Radiological and clinical union was evident in all patients with average duration of 18 weeks (16-20; Table 5).

\section{CONCLUSION}

We conclude that the results of fractures of distal third tibia not extending in to the lower $4 \mathrm{~cm}$ of tibia treated with interlock nailing found satisfactory. Meticulous planning and placement of nail at the center of wide metaphysis in anteroposterior and lateral is mandatory to avoid varus, valgus, and posterior tilt. Polar screw or temporary K-wire during surgery is very helpful. Samelevel fibula fracture fixation with plate or square nail is very effective for stability of reduction.

\section{REFERENCES}

1. Kumar A, Charlebois SJ, Cain EL, Smith RA, Daniels AU, Crates JM. Effect of fibular plate fixation on rotational stability of simulated distal tibial fractures treated with intramedullary nailing.J Bone Joint Surg Am 2003 Apr;85-A(4): 604-608.

2. Bedi A, Le TT, Karunakar MA. Surgical treatment of nonarticular distal tibia fractures. J Am Acad Orthop Surg 2006 Jul;14(7):406-416.

3. Robinson CM, McLauchlan GJ, McLean IP, Court-Brown CM. Distal metaphyseal fractures of the tibia with minimal involvement of the ankle: classification and treatment by locked intramedullary nailing. J Bone Joint Surg Br 1995 Sep;77(5):781-787.
4. Gorczyca JT, McKale J, Pugh K, Pienkowski D. Modified tibial nails for treating distal tibia fractures. J Orthop Trauma 2002 Jan;16(1):18-22.

5. Francois J, Vandeputte G, Verheyden F, Nelen G. Percutaneous plate fixation of fractures of the distal tibia. Acta Orthop Belg 2004 Apr;70(2):148-154.

6. Tornetta P III, Casey D, Creevy WR. Nailing proximal and distal tibia fractures. Rosemont (IL): Orthopaedic Trauma Association. Final Program \& Membership Directory; 2000. p. 131-132.

7. Mosheiff R, Safran O, Segal D, Liebergall M. The unreamed tibial nail in the treatment of distal metaphyseal fractures. Injury 1999 Mar;30(2):83-90.

8. Richter D, Ostermann PA, Ekkernkamp A, Hahn MP, Muhr G. Distal tibial fracture: an indication for osteosynthesis with an unreamed intramedullary nail? [German] Langenbecks Arch Chir Suppl Kongress 1997;114:1259-1261.

9. Oestern HJ, Tscherne H. Pathophysiology and classification of soft tissue injuries associated with fractures. In: Tscherne $\mathrm{H}$, Gotzen L, editors. Fractures with soft tissue injuries. Berlin: Springer-Verlag; 1984. p. 1-9.

10. Schmidt AH, Finkemeier CG, Tornetta P III. Treatment of closed tibial fractures. Instructional Course Lectures, the American Academy of Orthopaedic Surgeons. J Bone Joint Surg Am 2003;85:352-368.

11. Schmitt AK, Nork SE, Winquist RA. Intramedullary nailing of distal metaphyseal tibial fractures. Read at the Annual Meeting of the Orthopaedic Trauma Association, San Antino, TX; 2000. p. 13.

12. Tyllianakis M, Megas $P$, Giannikas D, Lambiris E. Interlocking intramedullary nailing in distal tibial fractures. Orthopedics 2000 Aug;23(8):805-808.

13. Yang SW, Tzeng HM, Chou YJ, Teng HP, Liu HH, Wong CY. Treatment of distal tibial metaphyseal fractures: plating versus shortened intramedullary nailing. Injury 2006 Jun;37(6): 531-535.

14. Moongilpatti Sengodan M, Vaidyanathan S, Karunanandaganapathy S, Subbiah Subramanian S, Rajamani SG. Distal tibial metaphyseal fractures: does blocking screw extend the indication of intramedullary nailing? ISRN Orthop $2014 \mathrm{Feb}$ 17;2014:542623.

15. Guo JJ, Tang N, Yang HL, Tang TS. A prospective, randomised trial comparing closed intramedullary nailing with percutaneous plating in the treatment of distal metaphyseal 
fractures of the tibia. J Bone Joint Surg Br 2010 Jul;92(7):984-988.

Erratum in: J Bone Joint Surg Br 2010 Dec;92(12):1717.

16. Dogra AS, Ruiz AL, Thompson NS, Nolan PC. Diametaphyseal distal tibial fractures - treatment with a shortened intramedullary nail: a review of 15 cases. Injury 2000 Dec;31(10):799-804.

17. Labronici PJ, Franco JS, da Silva AF, Cabral FMP, Soares MS, Lourenço PRBT, Hoffmann R, Fernandes HJA, dos Reis FB. Treatment of distal fractures of the tibia. Acta Ortop Bras 2009;17(1):40-45.
18. NorkSE,Schwartz AK, Agel J,HoltSK,SchrickJL, WinquistRA. Intramedullary nailing of distal metaphyseal tibial fractures. J Bone Joint Surg Am 2005 Jun;87(6):1213-1221.

19. Fan CY, Chiang CC, Chuang TY, Chiu FY, Chen TH. Interlocking nails for displaced metaphyseal fractures of the distal tibia. Injury 2005 May;36(5):669-674.

20. Goldsztajn F, Guimarães JM, Rocha TH, Correa M, Dias MV, Lemgruber L. Fraturas do terço distal dos ossos da perna: É necessário fixar a fíbula? Congresso Brasileiro de Trauma. Santos, SP, 2007. 